\title{
Tecnura
}

\section{Water Footprint: Two Different Methodologies}

\section{A Response to Sara Edith Bueno Pérez et al.}

\author{
Libor Ansorge ${ }^{1}$
}

Keywords: water footprint, volumetric water footprint, LCA water footprint, ISO 14046

Dear editor,

I read with great interest the article Implementation of the shortage method to determine the water footprint in the coastal area of San Blas, México on Volume 23 Number 62 (Pérez et al., 2019). The article describes three types of water footprint methodologies: by volume, by impact, and by scarcity. In reality, the one described as "scarcity water footprint" is a special type of impact water footprint. Over the last year, I reviewed several articles that made no distinction between these two methodologies and their principles. It should be noted that both methodologies were developed with different aims and are used for different applications (Hoekstra et al., 2009). The so-called "volumetric" water footprint according to Water Footprint Network (Hoekstra et al., 2011) is a tool for the management of water resources and is based primarily on the desire to illustrate the hidden links between human consumption and water use, and between global trade and water resources management (Ercin \& Hoekstra, 2012). Assessing sustainability by volumetric water footprint evaluation considers the environmental, social, and economic dimensions of sustainable water use. This methodology distinguishes three types of water footprints. The blue water footprint $\left(W F_{\text {blue }}\right)$ refers to the consumption of surface and ground freshwater resources $\left(W C_{\text {blue }}\right)$. The green water footprint $\left(W F_{\text {green }}\right)$ is the volume of green water (rainwater) consumed $\left(W C_{\text {green }}\right)$, which is particularly relevant in crop production. The grey water footprint $\left(W F_{\text {grey }}\right)$ is an indicator of the contamination degree of freshwater and is defined as the volume of freshwater required to assimilate the pollutant load according to existing environmental water quality standards (Mekonnen \& Hoekstra, 2011). The total water footprint is calculated by Equation (1):

$$
W F=W F_{\text {blue }}+W F_{\text {green }}+W F_{\text {grey }}=\sum W C_{\text {blue }, i}+\sum W C_{\text {green }, i}+\sum W C_{\text {grey }, i}
$$

On the other hand, the LCA water footprint is defined by ISO 14046 (ISO, 2014) and assesses the potential environmental impacts related to water associated with products, processes, or organizations. Economic or social impacts are typically outside the scope of the water footprint assessment under ISO 14046. Impacts related to water are associated with numerous environmental mechanisms, thus numerous category indicators are possible. The water footprint is calculated by Equation (2):

$$
W F_{j}=\sum\left(C F_{i, j} \times W U_{i, j}\right)
$$

1 PhD. Deputy Director for Research at T. G. Masaryk Water Research Institute. Czech Republic, Prague. Email: libor.ansorge@vuv.cz 
Where $W U_{i, j}$ represents water use from resource $i$ important for environmental impact category $j$, and $C F_{i, j}$ represents the characterization factor derived from a characterization model applied to turn an assigned water use into the environmental impact category. The LCA water footprint methodology also distinguishes between three types of water footprints. The "water availability footprint" assesses the impacts of water use related to products, processes, or organizations, as well as potential environmental impacts related to pressure on water availability. If water availability footprint only considered water quantity, it should be called "water scarcity footprint." The purpose of "water footprints addressing water degradation" is to give an assessment of the contribution of the product, process or organization to potential environmental impacts related to water quality. If only one impact category (e.g., eutrophication, etc.) is selected, then that impact category shall be identified in the qualifier of the water footprint (e.g., "water eutrophication footprint"). Unless all related impact categories are considered, the water footprint assessment cannot be identified without some qualifier (e.g., "non-comprehensive water footprint").

Because the article does not distinguish between these two methodologies, you can read "the fresh water scarcity methodology developed by Pfister, Koehler and Hellweg (2009) is mainly used to assess the water footprint in Latin America." This statement is inconsistent with previously published information (Martínez-Arce et al., 2018).

The next fundamental mistake represents a comparison with the article by Farell Baril et al. (2013). Farell Baril et al. calculated "freshwater ecotoxicity water footprint" based on a different methodological background and their results are incomparable with those reached by Pérez et al.

Since it is the role of independent reviewers to catch these kind of things, it is unfortunate that none of the original reviewers caught these issues.

\section{FUNDING}

This work did not receive any specific grant from funding agencies in the public, commercial, or notfor-profit sectors.

\section{DECLARATION OF COMPETING INTEREST}

The author have no conflicts of interest to declare.

\section{REFERENCES}

Ercin, A. E., \& Hoekstra, A. Y. (2012). Carbon and water footprints: Concepts, methodologies and policy responses. UNESCO. https://unesdoc.unesco.org/ ark:/48223/pf0000217181

Farell Baril, C., Turpin Marion, S., \& Suppen Reynaga, N. (2013). Huella de agua de uso público-urbano en México. Realidad, Datos y Espacio Revista Internacional de Estadística y Geografía, 4(1), 58-71. https://rde.inegi.org.mx/index.php/2013/01/07/ huella-de-agua-de-uso-publico-urbano-en-mexico/

Hoekstra, A. Y., Gerbens-Leenes, W., \& Meer, T. H. van der. (2009). Reply to Pfister and Hellweg: Water footprint accounting, impact assessment, and life-cycle assessment. Proceedings of the National Academy of Sciences, 106(40), E114-E114. https://doi. org/10.1073/pnas.0909948106

Hoekstra, A. Y., Chapagain, A. K., Aldaya, M. M., \& Mekonnen, M. M. (2011). The water footprint assessment manual: Setting the global standard. Earthscan. https://waterfootprint.org/media/downloads/TheWaterFootprintAssessmentManual_2.pdf

International Organization for Standardization. (2014). Environmental management-Water footprintPrinciples, requirements and guidelines (ISO Standard No. 14046:2014 https://www.iso.org/standard/43263.html

Martínez-Arce, A., Chargoy, J. P., Puerto, M., Rojas, D., \& Suppen, N. (2018). Water Footprint (ISO 14046) 
in Latin America, State of the Art and Recommendations for Assessment and Communication. Environments, 5(11), 114. https://doi.org/10.3390/ environments5110114

Mekonnen, M. M., \& Hoekstra, A. Y. (2011). National water footprint accounts: The green, blue and grey water footprint of production and consumption (No. 50; Value of Water Research Report Series). UNESCO-IHE. http://waterfootprint.org/media/downloads/Report50-NationalWaterFootprints-Vol1.pdf
Pérez, S. E. B., Flores, S. M., González, O. N., \& Mota, R. de H. (2019). Implementación del método de escasez en la determinación de la huella hídrica en la zona costera de San Blas, México. Tecnura, 23(62). https://doi.org/10.14483/22487638.15796

Pfister, S., Koehler, A., \& Hellweg, S. (2009). Assessing the Environmental Impacts of Freshwater Consumption in LCA. Environmental Science \& Technology, 43(11), 4098-4104. https://doi.org/10.1021/ es802423e 